\title{
Xylanase Activity of Streptomyces violascences BF 3.10 on Xylan Corncobs and its Xylooligosaccharide Production
}

\author{
W. Salupi ${ }^{a}$, Yopi ${ }^{b}$, \& A. Meryandini ${ }^{c, d, *}$ \\ aMajor Program of Biotechnology, Graduate School, Bogor Agricultural University \\ ${ }^{b}$ Biocatalyst and Fermentation Laboratory, Research Center for Biotechnology, Indonesian Institute of Science \\ Jalan Raya Bogor Km. 46 Cibinong, Indonesia \\ 'Biology Department, Faculty of Mathematics and Natural Science, Bogor Agricultural University \\ ${ }^{\mathrm{d}}$ Research Center for Bioresources and Biotechnology \\ Kampus IPB Dramaga, Bogor 16680, Indonesia \\ (Received 12-05-2014; Reviewed 05-06-2014; Accepted 27-08-2014)
}

\begin{abstract}
Corn is one of the important carbohydrate sources in Indonesia that is mainly used for food and industrial materials. In addition, the byproducts of corn, such as corncobs, have been reported as xylan-containing materials that can be utilized as substrate in xylooligosaccharides (XOS) production. XOS are natural prebiotic fibers that can enhance the performance of animal's digestive system. The main objective of this study was to exploit xylan from corncobs to produce XOS. The research consisted of extraction and production of xylan from corncobs and the synthesis of XOS from corncob-produced xylan. The corncob and Streptomyces violascens BF 3.10 xylanase is a collection of PPSHB IPB Laboratory. Corncobs xylan extracted by using alkaline method and reducting sugar was analyzed by dinitrosalicylic acid method. The xylan extraction from corncobs could produce $7.93 \%$ $(w / w)$ of xylan. The activity of $S$. violascens BF 3.10 xylanase on the substrate of concorb-produced xylan was $6.4 \mathrm{U} / \mathrm{mL}$ at the optimum temperature of $60^{\circ} \mathrm{C}$ in $50 \mathrm{mM}$ phosphate buffer with $\mathrm{pH}$ 5.5. The thin layer chromatography analysis indicated that $1 \%(\mathrm{w} / \mathrm{v})$ corn-cob xylan could produce XOS with degree of polymerization (DP) 3.92. XOS, with DP ranging from 2-4, could be used as a livestock feed mixture to stimulate the growth of normal microbes in the gastrointestinal tract of livestock.
\end{abstract}

Key words: corncobs, Streptomyces violascens BF 3.10, xylan, xylanase

\section{ABSTRAK}

Jagung merupakan sumber karbohidrat penting di Indonesia, khususnya untuk makanan dan bahan baku industri. Tongkol jagung adalah limbah prospektif yang mengandung xilan tinggi sehingga dapat digunakan sebagai substrat untuk memproduksi xilooligosakarida (XOS). XOS adalah serat prebiotik alami yang dapat membantu kesehatan saluran pencernaan. Penelitian ini bertujuan untuk memanfaatkan xilan dari limbah tongkol jagung untuk menghasilkan XOS. Penelitian ini meliputi ekstraksi xilan tongkol jagung, produksi xilanase dan produksi XOS dari xilan tongkol jagung. Tongkol jagung dan xilanase Streptomyces violascens BF 3.10 merupakan koleksi dari Laboratorium PPSHB IPB. Ekstraksi xilan tongkol jagung menggunakan metode alkali dan kadar gula dianalisa menggunakan metode dinitrosalicylic acid. Ekstraksi xilan dari tongkol jagung menghasilkan rendemen xilan 7,93\%. Aktivitas Streptomyces violascens BF 3.10 xilanase pada xilan tongkol jagung sebesar $6,4 \mathrm{U} / \mathrm{mL}$ pada suhu optimum $60^{\circ} \mathrm{C}$ dalam $50 \mathrm{mM}$ bufer fosfat $\mathrm{pH} 5.5$. Hasil analisis kromatografi lapis tipis, $1 \%$ xilan tongkol jagung pada kondisi optimum menghasilkan xilooligosakarida dengan nilai derajat polimerisasi (DP) 3,92. Xilooligosakarida (dengan DP antara 2-4) dapat digunakan sebagai campuran pakan ternak untuk merangsang pertumbuhan flora normal dalam saluran pencernaan ternak.

Kata kunci: Streptomyces violascens BF 3.10, tongkol jagung, xilan, xilanase

${ }^{*}$ Corresponding author:

E-mail: ameryandini@yahoo.com 


\section{INTRODUCTION}

Corn is one of the carbohydrate sources in Indonesia especially for feed and industrial raw materials. Based on its sugar composition, hemicellulose is classified as xylan, mannan, arabinoxylan, and arabinan. Corncobs consist of $38.99 \%(\mathrm{w} / \mathrm{w})$ crude fiber with the highest content of xylan (12.4\%) as compare to other agricultural by products such as rice straw, oil palm kernel, bagasse, cotton stalk, sorghum, tobacco stalk and soybean kernel (Richana et al., 2004). Xylan, which is the most abundant hemicellulose in monocotyledonous plants and hard wood, is also reported to interact with cellulose. Compared to xyloglucan, information about its critical backbone length required for interaction with cellulose, as well as about the influence of xylan substituents on this interaction is limited (Kabel et al., 2007). Xylan from corncobs can be used as a carbon source for the growth of xylanase producing bacteria.

Xylanase is a xylan hydrolytic enzyme. It can also hydrolyze the polymer of either xylose or xylooligosaccharides (XOS). Several actinomyces that have been reported to produce xylanase are Streptomyces (S.) galbus (Kansoh \& Nagieb, 2004), S. albus; S. chromofuscu (Rifaat, 2005), S. cyaneus SN32 (Ninawe\& Kuhad 2005), Streptomyces sp. 451-3 (Meryandini et al., 2007), S. lividans (Arias et al., 2007), S. bangladehienis (Al-Bari et al., 2007), Streptomyces sp. OM 09 (Ray, 2010), S. megasporus DSM 41476 (Qiu et al., 2010), Streptomyces sp. RCK-2010 (Kumar et al., 2010), Streptomyces sp. SWU10 (Deesukon et al., 2011), S. rameus (Bhosale et al., 2011), S. chartreusis L1105 (Zhuet al., 2012), S. griseorubens LH-3 (Cheng et al., 2013) and Streptomyces sp. ESRAA-301097 (El-Gendy \& El-Bondkly, 2014).

The products of hydrolyzing agricultural waste by xylanase are xylooligosaccharides. Xylooligosaccharides (XOS) have high economic value as food additive. XOS consumption in piglet can improve fermentation in the digestive tract so that it improves the growth of normal flora and production of short-chain fatty acid (Moura et al., 2008). In addition, XOS are able to function as fiber, so it might acts as a prebiotic (Yang et al., 2005). Fiber plays a role as a trigger for the increasing of beneficial bacteria, such as Lactobacillus and Bifidobacteria, in the intestine tracts. A prebiotic is a selectively fermented ingredient that allows specific changes, both in the composition and/or activity in the gastrointestinal microflora that confers benefits upon host well-being and health (Slavin, 2013). The ingested prebiotic stimulates the growth of the whole indigenous population of bifidobacteria, and the larger that population, the larger is the number of new bacterial cells appearing in feces (Roberfroid, 2007). Prebiotics can also suppress the growth of pathogen bacteria and decrease the level of ammonium in the feces of livestock (Yusrizal, 2012).

XOS resulted from degradation of xylan has an advantage for the growth of intestinal microbes. Previous research showed that XOS could suppress the growth of pathogen microbes and decrease ammonium in the feces of livestock (Yusrizal, 2012). The objective of this study is to hydrolyze corncobs as either xylan substrate or agricultural waste to produce XOS by using xylanase produced by S. violascens strain BF 310. S. violascens BF 3:10 are local isolates isolated from soil in National Park Bukit Dua Belas Jambi. Exploration of local isolates and local corn cob substrate contributes greatly to the utilization of agricultural waste. XOS produced from corn cobs can be used as a dietary supplement to improve the health of the digestive tract in cattle.

\section{MATERIALS AND METHODS}

\section{Microorganism}

The S. violascens BF 3.10 is a collection of PPSHB IPB Laboratory isolated from Bukit Dua Belas, Jambi. This isolate was used as a xylanase producing bacteria. For this purpose, S. violascens BF 3.10 was grown on the xylan media containing $0.5 \%$ xylan substrate from corncobs, $0.2 \%(\mathrm{w} / \mathrm{v})$ yeast extract; $0.5 \%(\mathrm{w} / \mathrm{v}) \mathrm{MgSO}_{4}$; $0.05 \%(\mathrm{w} / \mathrm{v}) \mathrm{K}_{2} \mathrm{HPO}_{4} ; 0.075 \%(\mathrm{w} / \mathrm{v}) \mathrm{KNO}_{3} ; 0.002 \%(\mathrm{w} / \mathrm{v})$ $\mathrm{FeSO}_{4} .7 \mathrm{H}_{2} \mathrm{O} ; 0.004 \%(\mathrm{w} / \mathrm{v}) \mathrm{CaCl}_{2} ; 0.1 \%(\mathrm{w} / \mathrm{v})$ glucose.

\section{Xylan Extraction}

Corncobs used in this experiment were "Silangan Dramaga 3". Delignification of corncob was performed by immersing 40 mesh corncobs flour in $1 \%(\mathrm{w} / \mathrm{v})$ $\mathrm{NaOCl}$ for $5 \mathrm{~h}$ at room temperature and the decanted was rinsed with aquadest and filtered. The solid part was a delignified corncob. The delignified corncobs were dried under the sun for $48 \mathrm{~h}$. Chemical analyzes were conducted to determine water, lignin, dry weight, hemicellulose and cellulose levels.

Corncobs xylan extraction was conducted by using a modified method of Richana et al. (2007). The dried delignified flour was immersed in $15 \%(\mathrm{w} / \mathrm{v}) \mathrm{NaOH}$ for $24 \mathrm{~h}$ at room temperature and filtered. The filtrate was neutralized with $37 \%(\mathrm{w} / \mathrm{v}) \mathrm{HCl}$ which was then centrifuged at $6000 \mathrm{rpm}$ for $30 \mathrm{~min}$. Ninety five percent (v/v) ethanol was added to the pellet with the proportion of pellet and ethanol was 1:3 and centrifuged at $6000 \mathrm{rpm}$ for $30 \mathrm{~min}$ to obtain pure xylan. The xylan was dried by using oven at $50^{\circ} \mathrm{C}$ for $48 \mathrm{~h}$ and crushed to the size of 80 mesh.

\section{Xylanase Activity and Xylanase Assay}

The 96 h culture of S. violascens BF 3.10 was inoculated in $100 \mathrm{~mL}$ of liquid medium containing $0.5 \%(\mathrm{w} / \mathrm{v})$ xylan corncobs by using crock borer $(1 \mathrm{~cm}$ in diameter $)$. The culture was incubated for $96 \mathrm{~h}$ at room temperature with agitation of $150 \mathrm{rpm}$ (Stuart orbital incubator s1500, Staffordshire, United Kingdom) (Meryandini et al., 2008). The enzymatic activity of the supernatant (assumed as a crude enzyme) was measured by using dinitrosalicylic (DNS) method (Meryandini et al., 2008; Akpinar et al., 2009; Utami et al., 2013) with xylose as a standard. Xylanase activity was tested by incubating crude enzyme in $0.5 \%$ beechwood xylan $(50 \mathrm{mM}$ phosphate buffer $\mathrm{pH}$ 6). The reaction was stopped by immersing the tubes in boiling water for $20 \mathrm{~min}$. Reducing sugar produced was measured at a wavelength of $540 \mathrm{~nm}$ (Hitachi, U-3900H, Tokyo, Japan). One unit xylanase activity was defined 
as the amount of enzyme producing $1 \mu \mathrm{mol}$ xylose per minutes.

\section{pH and Temperature Dependencies of Xylanase Activity}

Effect of $\mathrm{pH}$ on xylanase activity of the crude enzyme was examined at $\mathrm{pH}$ 3-4.5 (50 mM sodium citrate buffer), pH 5-6.5 (50 mM sodium phosphate buffer) and pH 7-10 (50 mM glycine $\mathrm{NaOH}$ buffer). Meanwhile, the effect of temperature on the xylanase activity was tested by reacting the enzyme with substrate at temperature ranging from $30-100{ }^{\circ} \mathrm{C}$, at the obtained-optimum $\mathrm{pH}$, for $30 \mathrm{~min}$. The xylanase activity was measured by DNS method (Miller, 1959). The stability of crude enzyme was analyzed by incubating the crude enzyme without substrate at different temperatures $\left(4^{\circ} \mathrm{C}, 30{ }^{\circ} \mathrm{C}\right.$ and obtained-optimum temperature) for $0,3,24,72$, and $96 \mathrm{~h}$.

\section{Xylanase Production}

Production of xylanase was induced by cultivating one crock borer ( $1 \mathrm{~cm}$ diameter, 96 hours old) into 100 $\mathrm{mL} 0.5 \%$ xylan-containing corncobs liquid. The culture was incubated with agitation append of (Stuart orbital incubator s1500, Staffordshire, United Kingdom) at room temperature for $96 \mathrm{~h}$. The crude enzyme was separated from its pellet by centrifugation at $12000 \mathrm{rpm} 4{ }^{\circ} \mathrm{C}$ for 20 min. The enzyme activity assay was analyzed by using DNS method (Meryandini et al., 2008).

\section{Xylan Hydrolysis Using Xylanase}

Enzymatic hydrolysis was performed by adding xylan corncobs $1 \%(\mathrm{w} / \mathrm{v})$ with $12.8 \mathrm{U}$ xylanase $S$. violascens BF 3.10 and incubated at room temperature with agitation append of $150 \mathrm{rpm}$. One milliliter of sample produced from hydrolysis was collected at 0, 3, 6, 12, 24 h. The total sugar content was measured by Fenol $\mathrm{H}_{2} \mathrm{SO}_{4}$ method (Dubois et al., 1956) and the reducing sugar was measured by DNS method (Miller, 1959), respectively. Polymerization degree was calculated according to the proportion of the total sugar content and reducing sugar.

Table 1. Composition of corncobs fiber before and after delignification

\begin{tabular}{lcc}
\hline Composition & $\begin{array}{c}\text { Before } \\
\text { delignification (\%) }\end{array}$ & $\begin{array}{c}\text { After } \\
\text { delignification (\%) }\end{array}$ \\
\hline Dry weight & 89.58 & 91.67 \\
Crude fiber & 25.15 & 26.09 \\
$\quad$ Cellulose & 33.10 & 34.07 \\
Hemicellulose & 17.90 & 37.92 \\
Lignin & 21.00 & 16.70 \\
Ash & 2.59 & 1.46 \\
Water & 7.99 & 5.11 \\
\hline
\end{tabular}

Note: Analysis in Laboratory of Feed Science and Technology, Department of Nutrition and Technology, Faculty of Animal Science, Bogor Agricultural University and Research Centre for Bioresources and Biotechnology, Institute of Research and Community Empowerment, Bogor Agricultural University.

\section{Thin Layer Chromatography}

Hydrolytic product was detected on chromatography paper (silica gel 60F254 Merck Art 20-20 cm, Darmstadt, Germany). The eluents used were n-butanol, acetic acid and aquadest with the proportion of 2:1:1, respectively. The sugar content was detected by heating the plate at $120{ }^{\circ} \mathrm{C}$ for $10 \mathrm{~min}$ after spraying with diphenilamine, anillyn, acetone and phosphoric acid (DAP).

\section{Statistical Analysis}

The data were analyzed descriptively to describe the effect of $\mathrm{pH}$ and temperature on xylanase activity.

\section{RESULTS AND DISCUSSION}

\section{Xylan Extraction}

The chemical compositions before and after delignification are shown in Table 1. The water content observed in this study was less than that reported by Richana et al. (2007) which was $6.43 \%$ (w/w). Meanwhile, ash content found in this study was higher than that reported by Koswara (1991), which was $1.33 \%$ (w/w). Water content was influenced by drying process, longer drying process yielded in little water content. Ash content could be influenced by mineral content. Ash content decreased after delignification process showed that the delignification process can reduce the mineral content.

Richana et al. (2004) stated that fiber content in corncobs was approximately $25 \%$ to $39 \%$ (w/w), while in this study the fiber content was $26.09 \%(w / w)$. The difference in fiber content in this study was related to the variety and the harvesting time of corn.

Delignification by using $1 \%(\mathrm{w} / \mathrm{v}) \mathrm{NaOCl}$ as a solvent could cleave carbon linkage on lignin structure. It could also open the linkage between lignin and polysaccharide so that the bacteria are able to use xylan easier (Lehninger, 1982). In this study, the level of hemicellulose after delignification increased to $37.92 \%(w / w)$. The use of $\mathrm{NaOCl}$ in delignification process was able to dissolve hemicellulose that finally increased its delignification concentration (Richana et al., 2007). Fifteen percent of $\mathrm{NaOCl}$ concentration could degrade cell wall structure and increase hemicellulose solubility. Compare to other solvents such as hot water, cold water, or $\mathrm{HCl}$, $\mathrm{NaOH}$ has been proved to have ability to dissolve xylan at high concentration. Beside $\mathrm{NaOCl}$ and $\mathrm{NaOH}$, ethanol can also increase hemicellulose content after delignification. The concentration ratio of 1:3 (supernatant : ethanol) could produce the highest yield (Richana et al., 2007).

In this study, the extraction of $500 \mathrm{~g}$ corn cobs produced $39.65 \mathrm{~g}$ of xylan $(7.93 \%)$. When compared with the fiber content, which was $26.09 \%(\mathrm{w} / \mathrm{w})$ (Table 1$)$ so that the ratio of pure xylan was $29.47 \%(w / w)$. The result found in this study was similar to that reported by Thu \& Preston (1999) who found the ratio of corn cob xylan was $28 \%(\mathrm{w} / \mathrm{w})$. The ratio of corn cob xylan may vary depends on the extraction process, the age of maize and maize varieties. 


\section{Xylanase Production from S. violascens BF 3.10}

Daily production of xylanase from S. violascens BF 3.10 and its activity measured at pH 5.5 under room temperature incubation is presented in Figure 1. Exponential growth of S. violascens BF 3.10 was observed until $48 \mathrm{~h}$ followed by the stationary phase which was ended after 72 h. Moreover, S. violascens BF 3.10 secreted extracellular xylanases at a low rate in the exponential phase and achieved the maximum xylanase production at the end of the stationary phase (72 h, Figure 1$)$. These enzymes were optimally expressed at the end of the exponential phase. but after the stationary phase $(72 \mathrm{~h})$, the xylanase activity was gradually decreased. The decreased xylanase activity could be due to the hydrolysis by autologous protease in the decline phase as were reported previously in Paenibacillus sp. strain NF1 (Zheng, 2014), Fomitopsis pinicola KMJ812 (Shin et al., 2010), Paenibacillus campinasensis G1-1 (Zheng et al., 2012) and Streptomyces spp. SKK1-8 (Meryandini et al., 2006 ).

The enzyme activity of xylanase from $S$. violascens BF 3:10 was optimum at $96^{\text {th }}$ hour, while the biomass of $S$. violascens BF 3:10 cells reached the highest level at $72^{\text {nd }}$ hour. These results showed that the optimum activity was not always at the time of optimum cell growth. Enzyme production of xylanase S. violascens BF 3:10 reached the optimum level when the growth rate and metabolic activity were in balance. The reduced carbon and nutrients availabilities promoted the dead of cells.

\section{Effects of $\mathrm{pH}$ and Temperature on Xylanase Activity}

The effect of $\mathrm{pH}$ on the xylanase activity produced by S. violascens BF 3.10 is shown in Figure 2. The xylanase showed a remarkable activity on a wide range of $\mathrm{pH}$, from 4 to 10 , in which the optimum activity was observed at $\mathrm{pH}$ 5.5. The effect of temperature on the enzyme activity was observed by incubating the enzyme with the substrate at several temperature ranges for 30 minutes and optimum pH 5.5 (Figure 3). Xylanase produced by $S$. violascens BF 3.10 displayed a remarkable activity at temperature range from 30 to $80{ }^{\circ} \mathrm{C}$ with maximum activity observed at $60{ }^{\circ} \mathrm{C}$. The highest

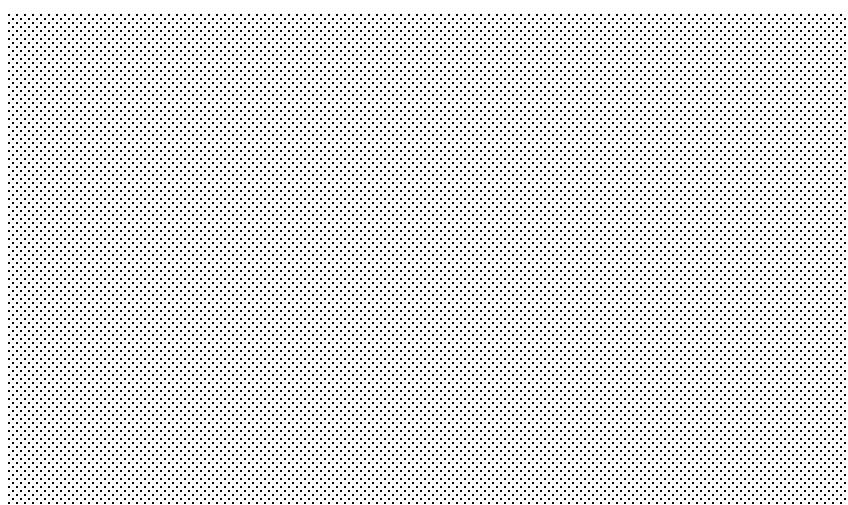

Figure 1. Xylanase activity $(-\diamond-)$ and cell biomass curve of S. violascens BF $3.10(-\square-)$ on $0.5 \%$ corncob xylan medium with $150 \mathrm{rpm}$ agitation at room temperature

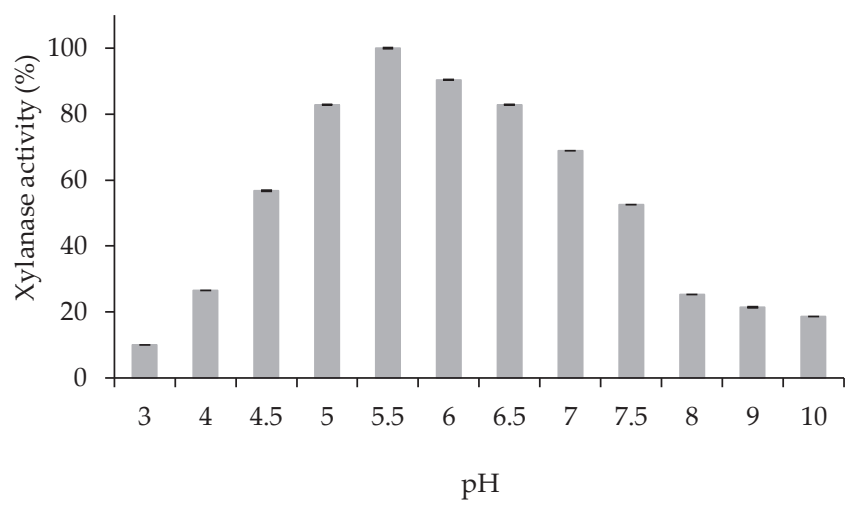

Figure 2. The effect of $\mathrm{pH}$ on S. violascens BF 3.10 xylanase activity at room temperature. $\mathrm{pH}$ 3-4.5 (buffer citrate 50 $\mathrm{mM}$ ), pH 5-6.5 (buffer phosphate $50 \mathrm{mM}$ ) and $\mathrm{pH}$ 7-10 (buffer Tris $\mathrm{HCl} 50 \mathrm{mM}$ ). The optimum activity of 2.60 $\mathrm{U} / \mathrm{mL}$ was observed at pH 5.5 and adjusted as $100 \%$.

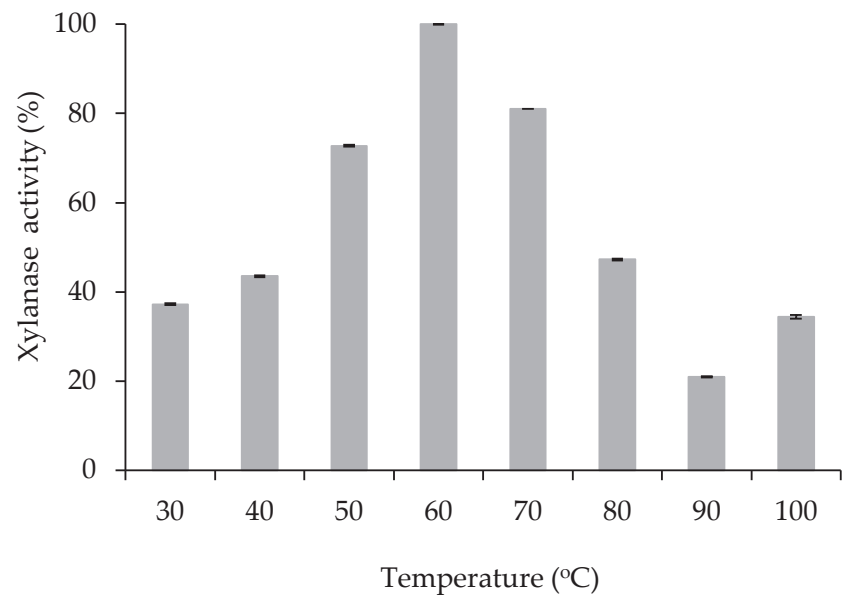

Figure 3. The effect of temperature on S. violascens BF $3.10 \mathrm{xy}-$ lanase activity measured at $\mathrm{pH}$ 5.5. The optimum temperature activity was obtained at $\mathrm{pH}$ 5.5. The optimum activity of $6.4 \mathrm{U} / \mathrm{mL}$ was observed at $60^{\circ} \mathrm{C}$ and adjusted as $100 \%$.

enzyme activity was reached at $\mathrm{pH} 5.5$ and temperature of $60{ }^{\circ} \mathrm{C}$. and his condition was similar to that reported by Ratanakhanokchau et al. (2009). The difference in enzyme activity at several temperature and $\mathrm{pH}$ levels could occur due to the variety of chemical interactions on protein (Bataillon, 2000).

Thermal stability was important in characterization of an enzyme. Thermal stability of xylanase produced by $S$. violascens $\mathrm{BF} 3.10$ examined by incubation at $4{ }^{\circ} \mathrm{C}$, $30{ }^{\circ} \mathrm{C}$, and $60^{\circ} \mathrm{C}$ are shown in Figure 4 . The enzyme was relatively stable upon incubation at $4{ }^{\circ} \mathrm{C}$ and $30{ }^{\circ} \mathrm{C}$ for $96 \mathrm{~h}$. However, the increased incubation temperature to $60{ }^{\circ} \mathrm{C}$ resulted in a decrease in activity up to $20 \%$. The rapid decrease in enzyme activity when it was incubated at $60{ }^{\circ} \mathrm{C}$ was caused by the inactivation of the enzyme by high temperature. Xylanase activity was unstable in preservation temperature more than $50{ }^{\circ} \mathrm{C}$ (Chapla et al. 2010). Protein stability is influenced by environmental conditions such as $\mathrm{pH}$ and temperature. Appropriate $\mathrm{pH}$ 


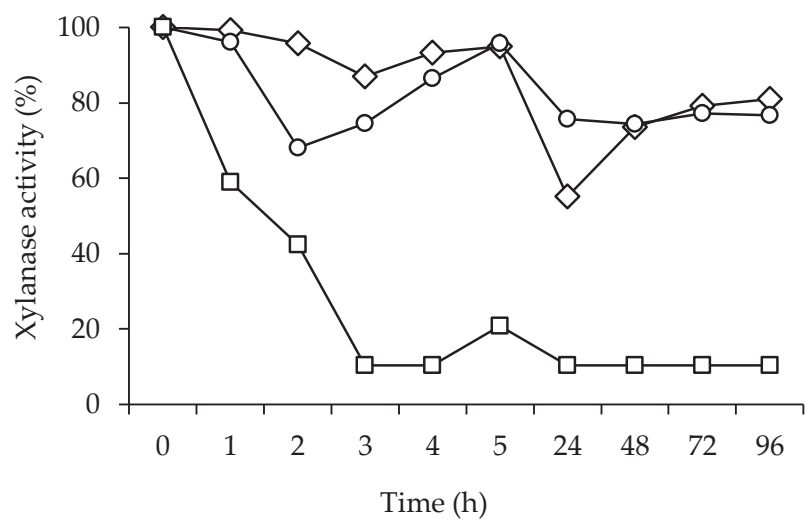

Figure 4. Stability curve of S. violascens BF 3.10 xylanase at various temperatures. The enzyme activity was measured at $\mathrm{pH} 5.5$ and $4{ }^{\circ} \mathrm{C}(-\diamond-), 30^{\circ} \mathrm{C}(-\mathrm{O}-)$ and $60^{\circ} \mathrm{C}(-\square-)$. The initial activity was $8.72 \mathrm{U} / \mathrm{mL}$ and adjusted as $100 \%$

and temperature will increase the interaction between the enzyme proteins that will prevent them from denaturation (Nath \& Rao, 2001).

\section{Hidrolysis of Xylan}

The pattern of xylan hydrolysis could be qualitatively seen on thin layer chromatography (TLC). The TLC plat showed that most of the hydrolysis product was XOS with spot located under the standard xylose (Figure 5). The result also indicated that XOS was produced at least after 3 hours of hydrolysis reaction. However, little amount of xylose was also produced. The increasing amount of the hydrolysis product was observed as indicated by thicker spots after $3 \mathrm{~h}$ incubations as compared to that of shorter incubation time. Following $3 \mathrm{~h}$ incubation, short xylooligosaccharide was started to be produced and thickened along with

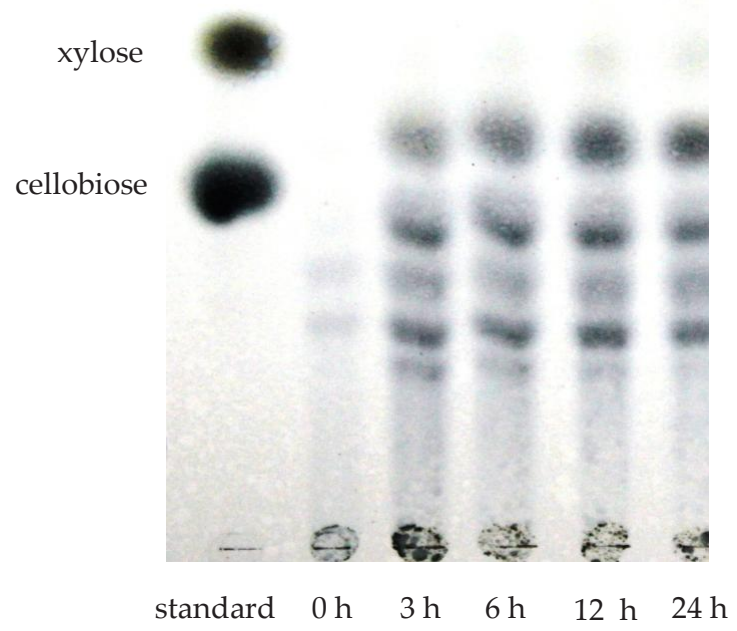

Figure 5. Thin layer chromatography analysis of corncobs hydrolysis product. The reaction was done by using $1 \%$ of corncobs with $1.6 \mathrm{U} / \mathrm{mL}$ enzyme S.violascens BF 3.10 at various incubation times $(0,3,6,12$, and $24 \mathrm{~h})$. the addition of the incubation time up to $24 \mathrm{~h}$. The spots observed in our TLC showed a variety of short xylooligosaccharide chains produced upon the hydrolysis. This result might be due to multiple substrate binding sites of the enzymes, as reported by Collins et al (2005), to produce several polysaccharides chains.

Based on the results reported by Chapla et al. (2012), using different concentrations of substrate at different incubation times played important role in enzymatic hydrolysis during XOS production. Increased xylan concentration in the reaction, from $1 \%(\mathrm{w} / \mathrm{v})$ to $3 \%(\mathrm{w} / \mathrm{v})$, did not increase the production of XOS. However, reduction of substrate concentration from $1.0 \%(\mathrm{w} / \mathrm{v})$ to $0.1 \%$ $(\mathrm{w} / \mathrm{v})$ decreased the production of XOS. The reduction of XOS production at high substrate concentration (more than $3 \%$ ) is probably due to saturation of the binding sites of xylanase occupied by the substrates and the decreased number of water molecules assisting hydrolysis reactions. In addition to substrate and hydrolysis time, the possible factors affecting hydrolysis process were bacterial properties and environmental condition.

The degree of polymerization (DP) expressed the number of polysaccharide chains that can be cleaved into monosaccharide. Smaller number of DP showed that the polysaccharides were depolymerized into shorter chain compounds. After $3 \mathrm{~h}$ of incubation the DP did not decrease. Longer hydrolysis time up to $24 \mathrm{~h}$ did not affect the DP (Table 2).

According to Wang (2009), production of $x y-$ looligosaccharides as a major product of the hydrolysis indicates that the enzyme is very active to digest xylose chain. These properties are characteristic of the endotype xylanase enzyme (endoxylanase). There are different characteristics of xylanase from variety of microorganisms, the xylanase of Bacillus sp. X13 has the capacity to produce cellobiose (Aygan \& Arikan, 2009).

Corncobs as an agricultural by product that could be utilized as a substrate for xylanase produced by S.violascens BF 3.10 to produce XOS. According to Richana et al. (2007), corncob is considered as a prospective raw material for either xylan industry or agricultural waste management. As xylan production from corncobs is considerably high, it is also promising to be developed for several oligosaccharide products, including prebiotic. The application of this product as a prebiotic was reported in cattle. This is because microbes in the cattle's rumen were able to produce xylanase that had the same characters as those obtained in this experiment, i.e. the xylanase optimum $\mathrm{pH}$ was 6-7, and optimum $50-60{ }^{\circ} \mathrm{C}$ (Budiansyah et al., 2010).

Tabel 2. Degree of polymerization of hydolysis product of corncobs by S. violascens BF 3.10

\begin{tabular}{cccc}
\hline $\begin{array}{c}\text { Time } \\
(\mathrm{h})\end{array}$ & $\begin{array}{c}\text { Total sugar } \\
(\mathrm{mg} / \mathrm{mL})\end{array}$ & $\begin{array}{c}\text { Reducting sugar } \\
(\mathrm{mg} / \mathrm{mL})\end{array}$ & $\begin{array}{c}\text { Degree of po- } \\
\text { lymerization }\end{array}$ \\
\hline 0 & 12.75 & 0.82 & 15.40 \\
3 & 10.82 & 2.30 & 4.70 \\
6 & 9.50 & 1.89 & 5.00 \\
12 & 10.83 & 2.50 & 4.30 \\
24 & 6.41 & 1.63 & 3.90 \\
\hline
\end{tabular}




\section{CONCLUSION}

Utilization of xylan as a substrate for xylanase to produce XOS is an interesting field to be explored. In this research, $500 \mathrm{~g}$ of corncobs could produce $39.65 \mathrm{~g}$ of xylan with $7.93 \%(w / w)$ yield. Further, xylan extracted from corncobs can be used as a substrate for the growth of $S$. violascens BF 3.10. The optimum time of xylanase activity of $S$. violascens BF $3.10\left(\mathrm{pH} \mathrm{5.5,60}{ }^{\circ} \mathrm{C}\right.$ ) to hydrolyze $1 \%(\mathrm{w} / \mathrm{v})$ corncobs substrate was 24 hour with the hydrolysis product is xylooligosaccharides (XOS) with polymerization degree of 3.92. Since XOS is considered as a prebiotic, xylan corncobs can be used as substrates to produce this prebiotic in a larger scale.

\section{ACKNOWLEDGEMENT}

Part of the research was funded by BOPTN for Anja Meryandini in 2014 and Start Up program from CRC 990. The authors express high gratitude to Misbakhul Munir for language editing.

\section{REFERENCES}

Akpinar, O, K. Erdogan, \& S. Bostanci. 2009. Enzyme production of xylooligosaccharide from selected agricultural waste. Food Bioprod. Proc. 87:145-151. http://dx.doi. org/10.1016/j.fbp.2008.09.002

Al-Bari, M. A. A, M. M. S. Rahman, M. A. U. Islam, M. E. Flores, \& M. S. A. Bhuiyan. 2007. Purification and characterization of a $\lambda$-(1,4)-endoxylanase of Streptomyces bangladeshiensis sp. J. Cell Mol. Biol. 1:31-36

Arias, E, H. Li, \& R. Morosoli. 2007. Effect of protease mutations on the production of xylanases in Streptomyces lividans. Can. J. Microbiol. 53:695-701. http://dx.doi. org/10.1139/W07-024

Aygan, A. \& B. Arikan. 2009. Production and characterization of multifunctional endoxylanase by Bacillus sp. X13. Turkish J. Biol. 33: 231-237

Bataillon, M, A. P. N Cardinali, N. Castillon, \& F. Duchiron. 2000. Purification and characterization of a moderately thermostable xylanase from Bacillus sp strain SPS-O. Enz. Microb. Technol. 26:187-192. http://dx.doi.org/10.1016/ S0141-0229(99)00143-X

Bhosale, J. H, S. R. Sukalkar, S. M. Z. Uzma, \& T. A. Kadam. 2011. Production of xylanase by Streptomyces rameus grown on agricultural wastes: Biotechnol. Bioinf. Bioeng. 1:505-512

Budiansyah, A, Resmi, K. G. Wiryawan, M. T. Soehartono, Y. Widyastuti, \& N. Ramli. 2010. Isolasi dan karakterisasi enzim karbohidrase cairan rumen sapi asal rumah potong hewan. Med. Pet. 2:36-43

Chapla, D. P, Pratima, \& S. Amita. 2012. Production of xylooligosaccharides from corncobs xylan by fungal xylanase and their utilization by probiotics. Biores. Technol. 115:215-221. http://dx.doi.org/10.1016/j.biortech.2011.10.083

Chapla, D, J. Divecha, D. Madamwar, \& A. Shah. 2010. Utilization of agro-industrial waste for xylanase production by Aspergillus foetidus MTCC 4898 under solid state fermentation and its application in saccharification. Biochem. Eng. J. 49:361-369. http://dx.doi.org/10.1016/j.bej.2010.01.012

Cheng, X, G. Chen, S. Huang, \& Z. Liang. 2013. Biobleaching effect of crude xylanase Streptomyces griseorubens LH-3 on Eucalyptus kraft pulp. Bioresources. 8:6424-6433. http:// dx.doi.org/10.15376/biores.8.4.6424-6433

Collins, T, C. Gerday, \& G. Feller. 2005. Xylanases, xylanase families and extremophilic xylanases. FEMS Microbiol. Rev. 29:3-23. http://dx.doi.org/10.1016/j.femsre.2004.06.005

Deesukon, W., Y. Nishimura, N. Harada, T. Sakamoto, \& W. Sukhumsiricharta. 2011. Purification, characterization and gene cloning of two forms of a thermostable endo-xylanase from Streptomyces sp. SWU10. Proc. Biochemistry 46: 2255-2262.

Dubois, M, K. A. Gilles, \& J. K. Hamilton. 1956. Colorimetric method for determination of sugar and related substances. Anal. Chem. 28:350-356. http://dx.doi.org/10.1021/ ac60111a017

El-Gendy, M. M. A, \& A. M. A. El-Bondkly. 2014. Optimization of solid state fermentation and leaching process parameters for improvement xylanase production by Endophytic Streptomyces sp. ESRAA-301097. J. Microb. Biochem. Technol. 6:154-166. http://dx.doi.org/10.4172/1948-5948.1000137

Kabel, M. A, H. Borne, J. P. Vincken, A. G. J. Voragen, \& H. A. Schols. 2007. Structural differences of xylans affect their interaction with cellulose. Carbo. Pol. 69:94-105. http:// dx.doi.org/10.1016/j.carbpol.2006.09.006

Kansoh, A. L., \& Z. A. Nagieb. 2004. Xylanase and mannanase enzymes from Streptomyces galbus NR and their use in biobleaching of softwood kraft pulp. Antonie van Leeuwenhoek 85:103-114. http://dx.doi.org/10.1023/B: ANTO.0000020281.73208.62

Koswara, J. 1991. Budidaya Jagung. Jurusan Budidaya Pertanian. Fakultas Pertanian. Institut Pertanian Bogor.

Kumar, A., R. Gupta, B. Shrivastava, Y. P. Khasa, \& R. C. Kuhad. 2010. Xylanase production from an alkalophilic actinomycete isolate Streptomyces sp. RCK-2010, its characterization and application in saccharification of second generation biomass. J. Mol. Catal. Enzym. 74:170-177. http://dx.doi.org/10.1016/j.molcatb.2011.10.001

Lehninger, A, L. 1982. Principles of Biochemistry. 1st edition. Worth Pub., New York.

Meryandini, A, D. Saprudin, P. A. Prihandono, A. Akhdiya, \& T. Hendarwin. 2007. Characterization of Streptomyces spp. 45I-3 Xylanase. Biotropia. 14:32-42.

Meryandini, A, N. Widhyastuti, \& Y. Lestari. 2008. Pemurnian dan karakterisasi xilanase Streptomyces sp KK1-8. Makara Sains 12:55-60

Meryandini, A, T. Hendarwin, D. Saprudin, \& Y. Lestari. 2006. Characterization of xylanase Streptomyces spp. SKK1-8. Hayati 13:151-155

Miller, G. L. 1959. Use of dinitrosalicylic acid reagent for determination of reducting sugar. Anal Chem. 31:426-428. http://dx.doi.org/10.1021/ac60147a030

Moura, P, S. Cabanas, P. Lourenco, F. Gírio, M. C. LoureiroDias, \& M. P. Esteves. 2008. In vitro fermentation of selected xylo-oligosaccharides by piglet intestinal microbiota. Food Sci. Technol. 41:1952-1961

Nath, D. \& M. Rao. 2001. pH dependent conformational and structural changes of xylanase from an alkalophilic thermophilic Bacillus sp. NCIM 59. Enz. Microb. Technol. 28:397-403. http://dx.doi.org/10.1016/S0141-0229(00)003598

Ninawe S. \& R. C. Kuhad. 2005. Use of xylan-rich cost effective agro-residues in the production of xylanase by Streptomyces cyaneus SN32. J. App. Microbiol. 99:1141-1148. http:// dx.doi.org/10.1111/j.1365-2672.2005.02711.x

Qiu, Z, P. Shi, H. Luo, Y. Bai, T. Yuan, P. Yang, S. Liu, \& B. Yao. 2010. A xylanase with broad $\mathrm{pH}$ and temperature adaptability from Streptomyces megasporus DSM 41476, and its potential application in brewing industry. Enz. Microb. Technol. 46:506-512. http://dx.doi.org/10.1016/ j.enzmictec.2010.02.003

Ratanakhanokchai, K, K. L. Kyu, \& T. Morakot. 2009. Purification and properties of a xylan-binding endoxylanase from 
alkaliphilic Bacillus sp. Strain K-1. App. Environ. Microbiol. 02:694-697.

Ray, R. R. 2010. Extra cellular endoxylanase production from solid state fermentation of dried grass by Streptomyces $\mathrm{sp}$ OM 09. J. Exp. Sci. 1:33-36

Richana, N., P. Lestina, \& T. T. Irawadi. 2004. Karakterisasi lignoselulosa dari limbah tanaman pangan dan pemanfaatannya untuk pertumbuhan bakteri RXA III-5 penghasil xilanase. J Penel. Pert. Tan. Pang. 23:171-176.

Richana, N., T. T. Irawati, N. M. Anwar, S. Illah, S. Khaswar, \& A. Yandra. 2007. Ekstraksi xilan dari tongkol jagung. J. Pascapanen 4: 38-43

Rifaat, H., M. Z. A. Nagieb, \& Y. M. Ahmed. 2005. Production of xylanases by Streptomyces species and their bleaching effect on rice straw pulp. App. Eol. Environ. Res. 4:151-160. http://dx.doi.org/10.15666/aeer/0401_151160

Roberfroid, M. 2007. Prebiotics: The concept revisited. J. Nutr. 137: 830S-837S

Shin, K., M. Jeya, J. K. Lee, \& Y. S Kim. 2010. Purification and characterization of a thermostable xylanase from Fomitopsis pinicola. J. Microbiol. Biotechnol. 20: 1415-1423. http:// dx.doi.org/10.4014/jmb.1003.03031

Slavin, J. 2013. Fiber and Prebiotics: Mechanisms and Health Benefits. Nutrients 5: 1417-1435. http://dx.doi.org/10.3390/ nu5041417

Thu Ng. V. \& T. R. Preston. 1999. Rumen environment and feed degradability in swamp buffaloes fed different supplement. Livestock Research Dev. 11(3). www.cepav.org. co.irrd/Irrd

Utami, W., A. Meryandini, \& K. G. Wiryawan. 2013. Characterization of bacterial mannanase for hydrolyzing palm kernel cake to produce manno-oligosaccharides prebiotics. Med. Pet. 36: 192-196. http://dx.doi.org/10.5398/medpet.2013.36.3.192

Wang, Y. 2009. Prebiotics: Present and future in food and technology. Food Res. Int: 42: 8-12. doi:10.1016/ j.foodres.2008.09.001

Yang, C. H, S. F. Yang, \& W. H. Liu. 2005. Produciton of xylooligosaccharfides from xylans by extracellular xylanases from Thermobida fusca. J. Agri. Food Chem. 55: 3955-3959. http://dx.doi.org/10.1021/jf0635964

Yusrizal, Y. 2012. Microbial and oligosaccharides treatments of feces and slurry in reducing ammonia of the poultry farm. Med. Pet. 12:152-156. http://dx.doi.org/10.5398/medpet.2012.35.3.152

Zheng, H. C, Y. H Liu, X. G Liu, J. L Wang, Y. Han, \& F. P Lu. 2012. Isolation, purification, and characterization of a thermostable xylanase from a novel s train, Paenibacillus campinasensis G1-1. J. Microbiol. Biotechnol. 22:930-958. http://dx.doi.org/10.4014/jmb.1110.10060

Zheng, H., M. Sun, L. Meng, H. Pei, X. Zhang, Z. Yan, W. Zeng, J. Zhang, J. Hu, F. Lu, \& J. Sun. 2014. Purification and characterization of a thermostable xylanase from Paenibacillus sp. NF1 and its application in xylooligosaccharides production. J. Microbiol. Biotechnol. 24:489-496. http://dx.doi. org/10.4014/jmb.1312.12072

Zhu, Y., X. Li, B. Sun, H. Song, E. Li, \& H. Song. 2012. Properties of an alkaline-tolerant, thermostable xylanase from Streptomyces chartreusis L1105, Suitable for xylooligosaccharide production. J. Food Scie.77:506-511. http://dx.doi. org/10.1111/j.1750-3841.2012.02671.x 